Research article

Open Access

\title{
Rheumatoid cachexia is associated with dyslipidemia and low levels of atheroprotective natural antibodies against phosphorylcholine but not with dietary fat in patients with rheumatoid arthritis: a cross-sectional study
}

Ann-Charlotte Elkan ${ }^{1}$, Niclas Håkansson ${ }^{2}$, Johan Frostegård ${ }^{3}$, Tommy Cederholm ${ }^{4}$ and

Ingiäld Hafström ${ }^{1}$

\begin{abstract}
${ }^{1}$ Karolinska Institute at the Department of Rheumatology, Karolinska University Hospital Huddinge, 14186 Stockholm, Sweden ${ }^{2}$ The National Institute of Environmental Medicine, Division of Nutritional Epidemiology, Karolinska Institute, 17177 Stockholm, Sweden ${ }^{3}$ Karolinska Institute at the Department of Medicine, Karolinska University Hospital Huddinge, 14186 Stockholm, Sweden

${ }^{4}$ Department of Public Health and Caring Science/Clinical Nutrition and Metabolism, Uppsala University, 75185 Uppsala, Sweden
\end{abstract}

Corresponding author: Ann-Charlotte Elkan, ann-charlotte.elkan@karolinska.se

Received: 23 Jan 2009 Revisions requested: 20 Feb 2009 Revisions received: 24 Feb 2009 Accepted: 10 Mar 2009 Published: 10 Mar 2009

Arthritis Research \& Therapy 2009, 11:R37 (doi:10.1186/ar2643)

This article is online at: http://arthritis-research.com/content/11/2/R37

(c) 2009 Elkan et al.; licensee BioMed Central Ltd.

This is an open access article distributed under the terms of the Creative Commons Attribution License (http://creativecommons.org/licenses/by/2.0), which permits unrestricted use, distribution, and reproduction in any medium, provided the original work is properly cited.

\begin{abstract}
Introduction Patients with rheumatoid arthritis (RA) have an increased risk for cardiovascular disease (CVD) independent of traditional risk factors. The aim of this study was to analyze the associations between diet, body composition, lipids and atheroprotective natural antibodies against phosphorylcholine (anti-PC) in patients with RA.
\end{abstract}

Methods A total of 80 RA patients (76\% women), mean age (standard deviation (SD)) 61.4 (12) years and median disease duration of 6 years, were assessed by food frequency questionnaire (FFQ), fatty acid profile in adipose tissue and whole-body dual energy $x$ ray absorptiometry (DXA). Rheumatoid cachexia was defined as fat free mass index below the 25th percentile and fat mass index above the 50th percentile of a reference population. Blood lipids, oxidized low-density lipoprotein (oxLDL) and anti-PC levels were determined.

Results The mean body mass index for the women and men was 25.0 and 27.0, respectively. Central obesity was found in 57\% of the women (waist circumference $>80 \mathrm{~cm}$ ) and in $89 \%$ of the men (waist circumference $>94 \mathrm{~cm}$ ). In all, $18 \%$ of the women and $26 \%$ of the men had rheumatoid cachexia. These patients had significantly higher total cholesterol $(P<0.033)$, LDL $(P<$
$0.029)$, and trendwise oxLDL $(P=0.056)$ as well as lower anti$\mathrm{PC} \operatorname{lgM}(P=0.040)$, higher frequency of hypertension (69\%) and metabolic syndrome (25\%) than those without. The patients reported a high dietary intake of saturated fat, which partly correlated with fatty acid composition in adipose tissue and significantly with disease activity. However, patients with or without cachexia did not differ with respect to dietary fat intake or intake of Mediterranean-like diet. Additionally, patients on a Mediterranean-like diet had high levels of anti-PC $(P<0.001)$.

Conclusions About one in five patients with low-active RA displayed rheumatoid cachexia. This condition was associated with high levels of LDL cholesterol, low levels of atheroprotective anti-PC and high frequency of hypertension, which is of interest in the context of CVD in RA. The cachexia could not be related to diet fat intake. However, patients on a Mediterranean-like diet had high anti-PC levels in spite of similar frequency of cachexia. High anti-PC levels may provide some protection against CVD.

Anti-PC: antibodies against phosphorylcholine; AT: adipose tissue; BMI: body mass index; BP: blood pressure; CRP: C-reactive protein; CVD: cardiovascular disease; DAS28: 28-joint Disease Activity Score; DXA: dual energy x ray absorptiometry; ESR: erythrocyte sedimentation rate; FA: fatty acid; FFM: fat free mass; FFMI: fat free mass index; FFO: food frequency questionnaire; FM: fat mass; FMI: fat mass index; HAQ: Health Assessment Questionnaire; HDL: high-density lipoprotein; IDF: International Diabetes Federation; LDL: low-density lipoprotein; MetS: metabolic syndrome; MUFA: monounsaturated fatty acids; oxLDL: oxidized low-density lipoprotein; PC: phosphorylcholine; PUFA: polyunsaturated fatty acid; RA: rheumatoid arthritis; SFA: saturated fatty acids; WC: waist circumference. 


\section{Introduction}

Rheumatoid arthritis (RA) is a chronic systemic inflammatory disease with higher mortality rates than observed in the general population $[1,2]$. This increased mortality is largely attributed to cardiovascular disease (CVD) [3]. The increase of CVD is suggested to be related to the effects of the chronic inflammation on the vascular endothelium, mainly through dysregulation of lipid metabolism.

Growing evidence points to inflammation in RA being associated with a worsening of the lipid profile [4,5], a factor already present early in the disease [6]. Dyslipidemia in RA is mainly presented by low concentrations of high-density lipoprotein (HDL), which is associated with an unfavorable cardiovascular risk. Total cholesterol and HDL levels in RA are inversely associated with the acute phase response, regardless of whether patients are treated with antirheumatic drugs or not. Furthermore, patients with RA have increased levels of oxidized lowdensity lipoprotein (oxLDL) in serum compared with healthy subjects, which may contribute to the increased risk of CVD in this patient group [7] as LDL oxidation probably has an important role in the pathogenesis of atherosclerosis [8].

Phosphorylcholine (PC) is a major ligand in oxLDL, exposed on platelet activating factor (PAF)-like phospholipids, which promote inflammation [9]. Antibodies against PC (anti-PC) of the IgM subclass are inversely associated with development of atherosclerosis in patients with established hypertension [10]. Further, low levels of anti-PC antibodies are associated with an increased risk of development of CVD [11].

In RA, anti-PC have not been studied in relation to CVD but we have recently shown that the level of anti-PC in serum increased when changing from a normal to a gluten-free vegan $\operatorname{diet}[12]$.

Another consequence of the course of RA disease is change in body composition, with reduced fat free mass (FFM), of which muscle mass is the largest component $[13,14]$. The decline in FFM is, in RA, often associated with increased fat mass (FM) and thus, with little or no weight loss, also with a maintained body mass index (BMI) $[15,16]$. This condition has been named 'rheumatoid cachexia' [13] and is believed to accelerate morbidity and mortality in RA [17].

Rheumatoid cachexia has been described in up to two thirds of RA patients and is suggested to be caused by cytokinedriven hypermetabolism and protein degradation [14,18]. However, it has also been found in patients with good disease control [14]. Another proposed cause is poor nutrition [19]. Dietary intake appears to be adequate in terms of energy and protein among patients with RA $[18,20]$. However, inadequate nutrient intake has also been reported [21,22]. Further support for a role of diet in the context of rheumatoid cachexia can be found in a recent report that addition of high dose oral amino acids for 12 weeks increased FFM in RA patients with rheumatoid cachexia [23].

During the last decade the use of food frequency questionnaires (FFQs) has become increasingly common to assess long-term dietary consumption. The accuracy of these has been proven in healthy individuals in terms of long-term dietary fat consumption, as this corresponds to fatty acid (FA) composition in adipose tissue [24-27].

The purpose of this study was to analyze if the type of diet over the previous year, determined by FFQ, was associated with body composition derangement and dyslipidemia in patients with RA. As a secondary goal, we also wanted to evaluate how rheumatoid cachexia relates to cardiovascular risk factors.

\section{Materials and methods \\ Patients}

A total of 80 consecutive outpatients with RA at the Rheumatology Department, Karolinska University Hospital Huddinge, Stockholm, Sweden were included in the study. Eligible patients were aged 18 to 80 years, had a diagnosis of RA [28] and had disease duration of $\geq 1$ year. The exclusion criteria were: current malignancy, severe heart failure according to the New York Heart Association (NYHA) classification >3 [29], severe renal failure (glomerular filtration rate (GFR) $<20 \mathrm{ml} /$ $\mathrm{min}$ ), chronic obstructive lung disease with emphysema, earlier gastric ulcer or intestinal surgery, known eating disorder or steroid injections within 2 weeks. The patient characteristics are shown in Table 1. Consequently, the patients had a fairly low disease activity according to mean Disease Activity Score (DAS28) [30] and a good functional ability as registered by Health Assessment Questionnaire (HAQ) [31]. Furthermore, $54 \%$ of the women and $68 \%$ of the men had hypertension, defined as a blood pressure above $140 / 90$ or treatment with antihypertensive drugs [32].

The study was approved by the Ethics committee at Karolinska Institute, Stockholm, Sweden (reference number 2006/593$31 / 2$ ), and was performed in accordance with the Helsinki declaration. Before entering the study the patients were given oral and written information, after which we received written informed consent from the patients.

\section{Dietary assessment}

The self-administered, semiquantitative FFQ was designed to classify individuals according to levels of average daily intake of selected nutrients from food and dietary supplements [33]. Participants were asked to report their frequency of use of 88 food items over the past year. There were nine possible frequency categories in increasing order from never or almost never to three times per day. Furthermore, there were openended questions about the quantity of some food items eaten daily by most Swedes; for example, milk, bread, coffee, and cheese [33]. The nutrient calculations were carried out using 


\begin{tabular}{|c|c|c|}
\hline & Women $(n=61)$ & Men $(n=19)$ \\
\hline Age, years & 60.8 (57.3 to 64.4$)$ & 63.4 (59.8 to 66.9 ) \\
\hline Disease duration, years ${ }^{a}$ & $6.0(2.0$ to 15.0$)$ & 5.0 (3.0 to 9.0$)$ \\
\hline Rheumatoid factor positive, N (\%) & $51(84)$ & $14(74)$ \\
\hline Erosive disease, N (\%) & $47(77)$ & $14(74)$ \\
\hline $\mathrm{ESR}, \mathrm{mm} / \mathrm{h}^{\mathrm{a}}$ & 16.0 (9.0 to 29.0$)$ & $12.0(9.0$ to 15.0$)$ \\
\hline C-reactive protein, $\mathrm{mg} / \mathrm{l}^{\mathrm{a}}$ & 2.0 (1.0 to 8.0$)$ & 3.0 (1.0 to 9.0$)$ \\
\hline DAS28 & 3.3 (3.0 to 3.6 ) & 2.6 (2.1 to 3.0$)$ \\
\hline HAQ score (0 to 3 ) & 0.7 (0.5 to 0.8$)$ & 0.5 (0.2 to 0.7$)$ \\
\hline Patients on DMARDs, N (\%) & $59(97)$ & $19(100)$ \\
\hline Patients on glucocorticoids, N (\%) & $17(28)$ & $3(16)$ \\
\hline Glucocorticoids, dose, mg & 4.3 (3.4 to 5.3$)$ & 4.2 (0.6 to 7.8$)$ \\
\hline Hypertension, N (\%) & $33(54)$ & $13(68)$ \\
\hline MetS, N (\%) & $12(20)$ & $12(63)$ \\
\hline
\end{tabular}

Data is presented as mean (95\% confidence intervals) for normally distributed variables and as median (interquartile range) for non-parametric variables.

a Median.

DAS28, 28-joint Disease Activity Score (where a value of $>5.1$ is regarded as high disease activity, $<3.2$ is regarded as low activity and $<2.6$ is regarded as remission); ESR, erythrocyte sedimentation rate; DMARD, disease-modifying antirheumatic drug (for example, methotrexate, sulfasalazine, hydroxychloroquine, cyclosporine, natriumaurotiomalat and azathioprine); HAQ, Health Assessment Questionnaire; MetS, metabolic syndrome.

nutrient composition values from the Swedish National Food Administration data [34]. The intake of nutrients was computed by multiplying the frequency of consumption of each food item by the nutrient content of the specified portions.

According to the Swedish National Food Administration the proportions (energy percentage $(E \%)$ ) of carbohydrate, protein and fat should be 55 to $65 \mathrm{E} \%, 10$ to $15 \mathrm{E} \%$ and 25 to $35 \mathrm{E} \%$, respectively, for normally active individuals. For less active individuals the recommendations are $55 \mathrm{E} \%, 16 \mathrm{E} \%$ and $28 \mathrm{E} \%$, respectively [35]. A Mediterranean diet was defined as a diet with high intake of fruits, vegetables, legumes, nuts, olive oil, fish, shellfish, a minimum of dairy products and lean meat [33].

\section{Biochemical measures}

Venous blood samples were drawn between 07:30 and 10:00 after an overnight fast. The biochemical variables were determined by standard laboratory methods with commercial kits. They included: C-reactive protein (CRP), erythrocyte sedimentation rate (ESR), plasma glucose, total cholesterol, LDL, HDL and triglycerides. The serum lipid concentrations were considered pathological when total cholesterol was $>5.0 \mathrm{mmol} / \mathrm{l}$, $\mathrm{LDL} \geq 3.0 \mathrm{mmol} / \mathrm{l}$, triglycerides $\geq 1.7 \mathrm{mmol} / \mathrm{l}$, for women $\mathrm{HDL}$ $<1.3 \mathrm{mmol} / \mathrm{l}$ and for men $\mathrm{HDL}<1.1 \mathrm{mmol} / \mathrm{l}$.

The samples had also been stored at $-70 \mathrm{C}$ before analyses. OxLDL was determined by use of a commercial kit (Mercodia,
Uppsala, Sweden) as per the manufacturer's instructions. Anti-PC lgM was also determined by use of a commercial kit (Athera CVDefine, Stockholm, Sweden) as per the manufacturer's instructions.

Subcutaneous abdominal fat cells were aspirated with a needle attached to a vacuum tube and stored at $-70 \mathrm{C}$ until analyzed. The FA composition of subcutaneous adipose tissue was analyzed by gas liquid chromatography as described previously [36]. The amounts of FA were given as the relative percentage of the sum of the FA analyzed.

\section{Body composition and metabolic syndrome}

BMI was calculated from weight $/$ height ${ }^{2}\left(\mathrm{~kg} / \mathrm{m}^{2}\right)$. In accordance with World Health Organization (WHO) standards, individuals with $\mathrm{BMl}$ values $<18.5 \mathrm{~kg} / \mathrm{m}^{2}$ are considered underweight, between 18.5 to 24.9 as normal, 25 to 29.9 as overweight and values greater than 30 indicate obesity [37].

Waist circumference (WC) was measured to identify centrally obese individuals. Waist was measured to the nearest $0.5 \mathrm{~cm}$ midway between the iliac crest and the lower rib margin.

According to the International Diabetes Federation (IDF), a waist circumference value less than $80 \mathrm{~cm}$ in women and 94 $\mathrm{cm}$ in men indicates low risk, $80-87.9 \mathrm{~cm}$ in women and $94-101.9 \mathrm{~cm}$ in men indicates intermediate risk, and a value 
above $88 \mathrm{~cm}$ in women and $102 \mathrm{~cm}$ in men high risk of type 2 diabetes, coronary heart disease or hypertension [38].

Metabolic syndrome (MetS) was defined according to the IDF [38]; that is, presence of central obesity (waist perimeter $\geq 80$ $\mathrm{cm}$ in females and $\geq 94 \mathrm{~cm}$ in males) plus two of the following four criteria: hypertriglyceridemia (triglycerides $\geq 1.7 \mathrm{mmol} / 1$ or specific treatment), unfavorable HDL level $(<1.3 \mathrm{mmol} / 1$ in females and $<1.1 \mathrm{mmol} / 1$ in males and or specific treatment), hypertension (systolic blood pressure $(\mathrm{BP}) \geq 130 \mathrm{mmHg}$ or diastolic $B P \geq 85 \mathrm{mmHg}$ or specific antihypertensive treatment) and fasting plasma glucose $\geq 5.6 \mathrm{mmol} / 1$ or prior diagnosis of type 2 diabetes mellitus.

Body composition was measured with total body dual energy $x$ ray absorptiometry (DXA) (GE-Lunar Prodigy, software enCore 2006, v. 10.20.105, Madison, Wisconsin, USA,). FFM and FM were expressed in absolute $\mathrm{kg}$, and FM also as percentage of total mass. The reference value for $\mathrm{FM} \%$ is $20 \%$ to $30 \%$ for women and $12 \%$ to $20 \%$ for men [39].

Fat free mass index (FFMI, $\mathrm{kg} / \mathrm{m}^{2}$ ) and fat mass index (FMI, kg/ $\mathrm{m}^{2}$ ) were also calculated. Age-matched and sex-matched data from a Swiss population of healthy adults $(2,986$ men and 2,649 women) were used to classify low FFM or excess FM [40]. The cutoff value for low FFM was defined as FFMI below the 10th percentile and obesity was defined as FMl above the 90th percentile, as defined by the reference population [40].

As there is no established criterion for rheumatoid cachexia we used both the definition by Engvall et al., who categorized the patients as rheumatoid cachectic if FFMI was below the 10th percentile and FMI above the 25th percentile [41], and also the definition composed of FFMI below the 25th percentile and FMl above the 50th percentile.

\section{Statistical analysis}

Data were presented as mean (confidence interval) or median (interquartile range) depending on whether the data were normally distributed or not. Differences between patient groups were assessed using the Student $t$ test and Mann-Whitney $U$ test, depending on the distribution of the analyzed variable.

To evaluate the association between intake of fatty acids in the diet and their relative content in adipose tissue Spearman correlations were used.

Table 2

\begin{tabular}{|c|c|c|c|c|}
\hline & Women with RA $(n=61)$ & Recommendations for females & Men with RA $(n=19)$ & Recommendations for males \\
\hline Energy, kcal & $1,668(1,537$ to 1,799$)$ & 2,200 & $2,402(2,123$ to 2,680$)$ & 2,700 \\
\hline Carbohydrate, $\mathrm{g}$ & 195 (178 to 212$)$ & 293 & 268 (238 to 298 ) & 369 \\
\hline Carbohydrate, E\% & 48 & 55 & 45 & 55 \\
\hline Protein, $\mathrm{g}$ & 73.0 (66.7 to 79.3$)$ & 86 & 103 (88.4 to 118$)$ & 107 \\
\hline Protein, $\mathrm{g} / \mathrm{kg}$ & $1.13(1.01$ to 1.23$)$ & & $1.18(1.0$ to 1.36$)$ & \\
\hline Protein, E\% & 18 & 16 & 17 & 16 \\
\hline Total fat, $g$ & 61.1 (55.8 to 66.4$)$ & 69 & $88.6(75.1$ to 102.1$)$ & 87 \\
\hline Total fat, E\% & 33 & 28 & 33 & 28 \\
\hline SFA, $g$ & 26.4 (23.7 to 29.0$)$ & 20 & 39.1 (31.9 to 46.2 ) & 30 \\
\hline SFA, E\% & 14 & 10 & 15 & 10 \\
\hline MUFA, g & $21.0(19.2$ to 22.8$)$ & 30 & 30.9 (26.5 to 35.2$)$ & 40 \\
\hline MUFA, E\% & 11 & 11 & 12 & 11 \\
\hline PUFA, g & 8.9 (7.9 to 9.8$)$ & 15 to 30 & 11.8 (9.8 to 13.8 ) & 15 to 30 \\
\hline PUFA, E\% & 4.8 & 5 & 4.4 & 5 \\
\hline Omega $3 \mathrm{FA}, \mathrm{g}$ & $1.9(1.8-2.1)$ & $\geq 3.0$ & $1.7(1.6-1.8)$ & $\geq 3.0$ \\
\hline Omega 3 FA, E\% & 1.0 & 1.3 & 0.6 & 1.3 \\
\hline Omega $6 \mathrm{FA}, \mathrm{g}$ & 6.9 (6.2 to 7.7$)$ & 10.8 & $11.0(10.4$ to 11.5$)$ & 10.8 \\
\hline Omega 6 FA, E\% & 3.7 & 3.6 & 4.1 & 3.6 \\
\hline
\end{tabular}

E\%, energy percentage; FA, fatty acid; MUFA, monounsaturated fatty acid; PUFA, polyunsaturated fatty acid; SFA, saturated fatty acid. 
FAs in adipose tissue are described as the percentage of the total FAs analyzed. Dietary FAs are described as the percentage of total fat intake as well as grams per day.

$P$ values $<0.05$ were considered significant. The statistical analysis program Statistica 7 (Stat Soft Scandinavia AB, Uppsala, Sweden), was used for statistical analysis.

\section{Results}

\section{Dietary intake and fatty acid profiles}

The mean dietary intake of total energy, carbohydrate, protein and fat is shown in Table 2. Compared with the Swedish Food Recommendations for individuals with low physical activity [35], the RA patients had a low intake of total energy. As to the diet composition, the patients reported lower carbohydrate intake and higher fat intake than recommended. The fat intake consisted of more saturated and less unsaturated fat than recommended.

Low total energy intake was mainly reported by patients with moderate inflammatory activity. Thus, female patients with DAS28 $>3.2$ had a lower mean energy intake than those with DAS28 $\leq 3.2(1,500 \mathrm{kcal} /$ day vs. $1,800 \mathrm{kcal} /$ day, $P=0.016)$. The proportions (E\%) of carbohydrate, protein and fat were similar in these two groups. Saturated fatty acid (SFA) intake was significantly associated with DAS28 $(r=0.26, P=$ 0.017).

In all, 65 patients $(81 \%)$ reported eating a normal western diet (46 of the women and all of the men), 3 patients (all women) were vegetarians and 12 (all women) followed a Mediterranean-like diet. The reported dietary intake of FAs correlated significantly with that in adipose tissue as to FA 14:0 (myristic acid), 18:2 n-6 (linoleic acid), 18:3 n-3 ( $\alpha$-linolenic acid), 20:4 n-6 (arachidonic acid), 20:5 n-3 (eicosapentaenoic acid), 22:5 n-3 (docosapentaenoic acid) and 22:6 n-3 (docosahexaenoic acid), but not with 16:0 (palmitic acid) and 18:1 n-9 (oleic acid) (Table 3 ). The FA in adipose tissue consisted predominantly of 18:1 n-9 (oleic acid) 51\%, 16:0 (palmitic acid), 22\% and 18:2 n-6 (linoleic acid) $11 \%$.

When analyzing the adipose FA content for the different selfreported diet groups, it was found that subjects compliant to Mediterranean-like or vegetarian diets had a more favorable FA profile; that is, with higher polyunsaturated fatty acids (PUFAs) than those reporting to eat a normal Western diet, Table 4.

\section{Serum lipids and anti-PC IgM}

Lipid mean values for women with RA with normal Western diet and with the Mediterranean-like/vegetarian diets are presented in Table 4. There were no significant differences between the diet groups. A total of $53 \%$ of the women and $32 \%$ of the men had cholesterol $>5.0 \mathrm{mmol} / \mathrm{l}$. Low HDL levels were found in $3 \%$ of the women and $5 \%$ in the men. High LDL levels were present in $51 \%$ of the women and in $32 \%$ of the men. Corresponding figures for triglycerides were $1 \%$ and $37 \%$ respectively. Concerning oxLDL, no reference values exist.

However, anti-PC IgM levels differed significantly between patients in the different self-reported diet groups. Women with Mediterranean-like diet had significantly higher median level compared with those with self-reported normal Western diet $(p<0.001)$, Table 4.

\section{Anthropometrical assessments and body composition measurement}

As shown in Table 5 the change in body weight from start of RA disease to the present investigation was fairly small for both sexes. BMI indicated that both women and men were overweight. Only one of the patients had BMI $<18.5$. A total of $55 \%$ of the patients had a BMI $>25$. Central obesity was found in $57 \%$ of the women $(\mathrm{WC}>80 \mathrm{~cm}$ ) and in $89 \%$ of the men (WC $>94 \mathrm{~cm}$ ). In all, $20 \%$ of the women and $63 \%$ of the men could be diagnosed to have MetS according to IDF guidelines [38].

Body composition data are shown in Table 5 . In all, $31 \%$ of the women and $53 \%$ of the men had a FMl above the 90th percentile of the reference population, implying that they could be classified as obese. Reduced FFMI, that is, below the 10th percentile of a reference population, was registered in $26 \%$ and $21 \%$ of the women and men, respectively. Furthermore, $18 \%$ of the women and $26 \%$ of the men were assessed to have rheumatoid cachexia when using the definition of FFMI below the 25th percentile and $\mathrm{FMl}$ above the 50th percentile. By the definition of FFMI below the 10th percentile and FMI above the 25th percentile, $18 \%$ and $21 \%$ of the women and men, respectively, were assessed to have rheumatoid cachexia. FFM correlated with disease duration $(r=-0.30, p=$ 0.008), in contrast to FM.

\section{Relationship between body composition and serum lipids as well as anti-PC antibodies and inflammatory markers}

Patients with low FFMI, below the 10th or the 25th percentile of healthy adults, had serum lipid and anti-PC levels similar to the rest of the patients [Additional data file 1]. Patients with FMl above the 50th percentile had lower HDL and higher triglycerides than the other patients. When combining low FFMI and high FMl according to the two proposed definitions of rheumatoid cachexia, it was evident that the patients with FFMI $<25$ th percentile in combination with FMI $>50$ th percentile had higher LDL, cholesterol and trendwise oxLDL, as well as significantly lower values of anti-PC $\operatorname{lgM}(p=0.040)$, than those without this derangement in their body composition.

With regard to DAS28 and CRP, there were no significant differences between any of the body composition groups (as defined in [Additional data file 1]) and those not belonging to 
Table 3

Spearman correlation coefficients between relative (\% of total fat) fatty acid (FA) diet intake calculated from food frequency questionnaire (FFQ) and FA in adipose tissue

\begin{tabular}{|c|c|c|c|c|c|c|c|c|c|}
\hline & 14:0 (FFQ) & 16:0 (FFQ) & $\begin{array}{c}\text { 18:1 n9 } \\
\text { (FFQ) }\end{array}$ & $\begin{array}{c}\text { 18:2 n6 } \\
\text { (FFQ) }\end{array}$ & $\begin{array}{c}18: 3 \text { n3 } \\
\text { (FFQ) }\end{array}$ & $\begin{array}{c}20: 4 \text { n6 } \\
\text { (FFQ) }\end{array}$ & $\begin{array}{c}20: 5 \mathrm{n} 3 \\
\text { (FFQ) }\end{array}$ & $\begin{array}{c}22: 5 \mathrm{n} 3 \\
\text { (FFQ) }\end{array}$ & $\begin{array}{c}22: 6 \text { n3 } \\
\text { (FFQ) }\end{array}$ \\
\hline $14: 0$, AT & $0.27^{\star \star}$ & & & & & & & & \\
\hline $16: 0$, AT & & -0.12 & & & & & & & \\
\hline 18:1 n9, AT & & & 0.21 & & & & & & \\
\hline 18:2 n6, AT & & & & $0.50^{\star}$ & & & & & \\
\hline $18: 3$ n3, AT & & & & & $0.48^{\star}$ & & & & \\
\hline 20:4 n6, AT & & & & & & $0.64^{\star}$ & & & \\
\hline $20: 5$ n3, AT & & & & & & & $0.71^{*}$ & & \\
\hline $22: 5 \mathrm{n} 3$, AT & & & & & & & & $0.78^{\star}$ & \\
\hline $22: 6$ n3, AT & & & & & & & & & $0.82^{*}$ \\
\hline
\end{tabular}

${ }^{\star} P<0.001,{ }^{\star \star} P<0.05$

$\mathrm{AT}=$ adipose tissue.

the respective group. However, when separating the patients according to the DAS28 level it was found that patients with DAS28 $\geq 3.2$ had significantly higher FM\% (38.0 vs. 35.3, $p=$ 0.032 ), lower FFM (43.5 vs. $48.5 \mathrm{~kg}, \mathrm{p}=0.018$ ) and lower FFM/FM ratio (1.6 vs. $2.1, p=0.031$ ) than those with DAS28 $\leq 3.2$.

\section{Relationship between body composition and diet groups as well as presence of hypertension and MetS}

There were no significant differences in intake of energy or fat (total SFA or total PUFA, also separated by total omega 3 and omega 6) between those who were considered to have rheumatoid cachexia or not, irrespective of definition. Neither did the frequency of patients with the self-reported Mediterranean and vegetarian diets differ between these groups (data not shown).

Patients with FMl above the 50th percentile and patients with rheumatoid cachexia, defined as FFMI <25th percentile in combination with FMI $>50$ th percentile, had the highest frequencies of hypertension and MetS [Additional data file 1]. Furthermore, we found that patients with hypertension had significantly lower values of anti-PC $\operatorname{lgM}$, median (interquartile range (IQR)) of 39.9 (30.1 to 73.8), than those with normal blood pressure, median (IQR) of 54.5 (41.6 to 160.7) ( $p=$ 0.046 ). Treatment with glucocorticoids and mean dose given did not differ between those who were cachectic and those not (data not shown).

\section{Discussion}

This study shows that ambulatory patients with RA of low disease activity were reported to have a diet intake high in saturated fat. They were in general centrally obese and a fifth had rheumatoid cachexia. A large proportion of the patients had hypertension and MetS, especially those with high FM and rheumatoid cachexia, conditions associated with high levels of oxLDL and low levels of anti-PC. Patients compliant with Mediterranean and vegetarian diets did not differ in body composition from the rest of the patients, but had a higher content of PUFA in adipose tissue and significantly higher serum levels of the atheroprotective anti-PC.

The patients had, according to the FFQ, a lower than recommended caloric intake. It is unclear if this was a real difference or a consequence of underreporting. However, underreporting seems most probable as earlier comparisons between FFQ and weighed diet records concerning fat intake showed lower total intake registered by FFQ than the weighed diet, whereas the proportions of fat components were similar [27].

With regard to the caloric proportions of the diet, our patients had a higher intake of saturated fat and lower intake of unsaturated fat compared to the Food Recommendations in Sweden [35]. A high fat intake has also been noted in RA patients in the USA, of which $40 \%$ were obese [21].

The reliability of the long-term fatty acid intake according to the FFQ was verified by the significant correlations found between the PUFAs ingested and those in adipose tissue. PUFAs in adipose tissue are largely exogenous and hence valid markers to assess dietary intake $[42,43]$. By contrast, SFAs and monounsaturated fatty acids (MUFAs) are not considered to be good biomarkers of intake because they are also endogenously synthesized [42,44], which was evident in the RA patients with no significant correlations concerning 16:0 and 18:1 n-9. Furthermore, the noted significant correlation between 14:0 FA in diet and adipose tissue verifies a report by Wolk et al. that this FA is also a valid biomarker for FA intake [45]. 
Fatty acids in adipose tissue and serum levels of lipids and anti-PC IgM in women with rheumatoid arthritis (RA), separated for diet

Normal diet $(n=46) \quad$ Mediterranean-like diet $(n=12) \quad P$ value Mediterranean-like and vegetarian diets $(n=\quad P$ value 15)

\begin{tabular}{|c|c|c|c|c|c|}
\hline \multicolumn{6}{|l|}{ Adipose tissue: } \\
\hline SFA & 29.2 (28.4 to 29.9$)$ & 29.1 (27.5 to 30.7$)$ & 0.60 & 28.8 (27.5 to 30.1$)$ & 0.90 \\
\hline 14:0 & 3.3 (3.1 to 3.5$)$ & 3.4 (3.1 to 3.8 ) & 0.60 & 3.5 (3.2 to 3.8 ) & 0.43 \\
\hline 16:0 & 21.7 (21.2 to 22.2$)$ & 21.7 (20.4 to 23.1$)$ & 0.92 & 21.4 (20.2 to 22.5$)$ & 0.55 \\
\hline MUFA & $57.4(56.7$ to 58.1$)$ & 56.1 (54.6 to 57.6$)$ & 0.06 & 55.8 (54.4 to 57.2$)$ & 0.016 \\
\hline $16: 1 \mathrm{n} 7$ & 6.5 (6.0 to 6.9$)$ & 6.0 (5.3 to 6.6$)$ & 0.30 & 5.8 (5.2 to 6.4$)$ & 0.13 \\
\hline $18: 1 \mathrm{n} 9$ & 51.4 (50.9 to 52.0$)$ & 50.2 (48.9 to 51.2 ) & 0.05 & $50.0(49.0$ to 51.0$)$ & 0.019 \\
\hline Omega 3 & 1.8 (1.7 to 1.9$)$ & 2.1 (1.7 to 2.6$)$ & 0.039 & 2.2 (1.8 to 2.6$)$ & 0.009 \\
\hline $18: 3$ n3 & 1.1 (1.0 to 1.2$)$ & $1.1(0.93$ to 1.2$)$ & 0.72 & 1.1 (1.0 to 1.3$)$ & 0.22 \\
\hline $20: 5$ n3 & $0.14(0.12$ to 0.16$)$ & $0.19(0.12 \text { to } 0.25)^{*}$ & 0.08 & $0.15(0.11 \text { to } 0.25)^{*}$ & 0.16 \\
\hline $22: 5$ n3 & 0.33 (0.29 to 0.37$)$ & 0.40 (0.31 to 0.50$)$ & 0.06 & 0.39 (0.29 to 0.48$)$ & 0.11 \\
\hline $22: 6$ n3 & $0.32(0.28$ to 0.36$)$ & $0.47(0.25 \text { to } 0.59)^{*}$ & 0.07 & $0.47(0.20 \text { to } 0.60)^{*}$ & 0.13 \\
\hline Omega 6 & 11.0 (10.6 to 11.3 ) & $12.0(10.7$ to 13.2$)$ & 0.06 & $12.6(11.2$ to 14.1$)$ & 0.004 \\
\hline $18: 2$ n6 & 10.1 (9.7 to 10.5$)$ & 11.2 (9.8 to 12.5$)$ & 0.06 & $11.9(10.4$ to 13.4$)$ & 0.003 \\
\hline $20: 4$ n6 & $0.40(0.36$ to 0.44$)$ & 0.39 (0.31 to 0.46$)$ & 0.81 & $0.32(0.26 \text { to } 0.45)^{*}$ & 0.35 \\
\hline \multicolumn{6}{|l|}{ Serum lipids: } \\
\hline Cholesterol, mmol/l & 5.3 (5.0 to 5.6$)$ & 5.1 (4.7 to 5.6$)$ & 0.60 & 5.1 (4.8 to 5.5$)$ & 0.57 \\
\hline $\mathrm{HDL}, \mathrm{mmol} / \mathrm{l}$ & $1.9(1.7$ to 2.0$)$ & 1.9 (1.4 to 2.4$)$ & 0.97 & 1.9 (1.5 to 2.3$)$ & 0.86 \\
\hline LDL, mmol/l & 2.9 (2.7 to 3.2$)$ & 2.8 (2.3 to 3.2$)$ & 0.58 & 2.8 (2.3 to 3.2$)$ & 0.52 \\
\hline OxLDL, U/I & $62.1(55.7$ to 68.4$)$ & 59.4 (50.0 to 68.9 ) & 0.67 & 58.8 (51.2 to 66.3$)$ & 0.57 \\
\hline Triacylglycerol, mmol/l & $0.98(0.88$ to 1.1$)$ & $1.0(0.82$ to 1.2$)$ & 0.63 & $1.0(0.81$ to 1.1$)$ & 0.95 \\
\hline anti-PC $\operatorname{lgM}, \mathrm{U} / \mathrm{ml}_{\mathrm{a}}$ & 43.5 (30.3 to 65.5$)$ & 198.2 (171.6 to 209.2$)$ & $<0.001$ & 188.2 (63.3 to 208.1$)$ & $<0.001$ \\
\hline
\end{tabular}

Values are means (95\% confidence interval) and amedians (interquartile range). The fatty acids in adipose tissue are expressed as a percentage of total fat. Significant results are in bold.

Anti-PC IgM, antibodies against phosphorylcholine IgM; FA, fatty acid; HDL< high-density lipoprotein; LDL, low-density lipoprotein; MUFA, monounsaturated fatty acid; oxLDL, oxidized low-density lipoprotein; PUFA, polyunsaturated fatty acid; SFA, saturated fatty acid.

When comparing the proportions of FAs in the adipose tissue in our RA patients with healthy subjects from different countries (Sweden, Denmark, USA, Spain and Costa Rica), our RA patients had higher proportions of SFA and lower proportions of PUFA than healthy subjects from the above-mentioned countries $[25,42,43,46,47]$. However, the SFA and PUFA content of adipose tissue was similar to that described in RA patients from the south of Sweden [48].

The patients reported in general a high intake of saturated fat. This high intake was also reflected in the FA composition of the adipose tissue. However, we did not find that the FA intake differed between cachectic and non-cachectic patients. Adherence to a Mediterranean diet did not differ either between cachectic and non-cachectic patients. Thus, diet as analyzed here does not seem to cause the derangement of body composition leading to cachexia. This finding is in accordance with the known difficulties of treating cachexia with diet. However, recently supplements with amino acids have been shown to increase muscle mass [23]. By contrast, the high intake of dietary fat may have contributed to the dyslipidemia displayed by the patients.

With regard to dietary therapies, 33\% to $75 \%$ of RA patients believe that food plays an important role in their disease, and $20 \%$ to $50 \%$ have tried dietary manipulation in an attempt to relieve symptoms $[49,50]$. The present finding that dietary intake of SFAs was significantly associated with disease activity focuses on the immunosuppressive effect of unsaturated FAs. In the scientific community there is, however, no consensus on dietary recommendations to patients with RA. Evidence may emerge that, for patients at an advanced disease stage, a high-protein diet may be recommended and, for patients with early RA, restriction of excessive energy intake may be benefi- 
Table 5

Anthropometry and body composition measurement in rheumatoid arthritis (RA) patients

\begin{tabular}{|c|c|c|}
\hline & Women $(n=61)$ & Men $(n=19)$ \\
\hline Weight change since disease onset, $\mathrm{kg}$ & $2.3(-0.8$ to 5.9$)$ & $4.4(-2.2$ to 8.0$)$ \\
\hline $\mathrm{BMl}, \mathrm{kg} / \mathrm{m}^{2}$ & 25.0 (23.6 to 26.3$)$ & $27.0(25.7$ to 29.1$)$ \\
\hline Waist circumference, $\mathrm{cm}$ & 85 (81 to 89$)$ & $105(100$ to 110$)$ \\
\hline Central obesity (WC >80 cm in women, $>94 \mathrm{~cm}$ in men), $\mathrm{N}(\%)$ & $35(57)$ & $17(89)$ \\
\hline $\mathrm{FM}$, total, $\mathrm{kg}$ & 25.8 (22.8 to 28.7$)$ & 27.9 (23.4 to 32.5$)$ \\
\hline FM, total, \% & 37.8 (35.7 to 39.9$)$ & $31.7(28.1$ to 35.2$)$ \\
\hline $\mathrm{FMI}, \mathrm{kg} / \mathrm{m}^{2}$ & $8.8(6.5 \text { to } 11.4)^{\mathrm{a}}$ & $8.6(7.2$ to 9.9$)$ \\
\hline FFM, total, kg & $42.0(40.6$ to 43.5$)$ & $61.2(58.6$ to 63.8$)$ \\
\hline $\mathrm{FFMl}, \mathrm{kg} / \mathrm{m}^{2}$ & $15.5(15.1$ to 15.9$)$ & $18.9(18.2$ to 19.6$)$ \\
\hline
\end{tabular}

Data is presented as mean (95\% confidence interval) for normally distributed variables and as median (interquartile range) for non-parametric variables.

aMedian

BMl, body mass index; FFM, fat free mass; FFMI, fat free mass index; FM, fat mass; FMI, fat mass index; WC, waist circumference.

cial to prevent obesity [51]. A scientific basis for a role of dietary therapy in RA has grown in the last few years, although there is still no agreement on the nature of the optimum diet [52].

Several of the RA patients had dyslipidemia, hypertension and MetS, most frequently patients with high FM and rheumatoid cachexia. Of the lipids, oxLDL might be especially important as it has proinflammatory and immune stimulatory properties $[53,54]$. It has previously been detected in synovia from RA patients [55], and is suggested to be of importance in the pathogenesis of CVD [8]. Even though there are no existing reference values for oxLDL, the present patients had higher levels than earlier reported for healthy people, with mean (SD) values of $42.2 \mathrm{U} / \mathrm{I}( \pm 14.7)$ and mean (95\% confidence interval (CI)) $48 \mathrm{U} / \mathrm{l}$ (35 to 68) [7,56]. Additionally, when compared with RA patients from Korea who had a mean (SD) value of 53.0 U/l ( \pm 20.9) [7], our patients had higher levels, a difference that might be secondary to different diet habits.

One novel finding herein is that anti-PC levels decreased in patients with rheumatoid cachexia. Low anti-PC levels could predispose patients to cardiovascular disease $[10,11]$ and might thus be one explanation for the increased morbidity in rheumatoid cachexia. The cause of this association is not known.

Also, the very high levels of anti-PC in patients on a Mediterranean diet is of great interest, as patients on this diet are reported to have a lower frequency of CVD $[57,58]$. In RA anti$P C$ have not been studied in relation to CVD, but we have recently shown that the levels of anti-PC in serum increased in RA patients when changing from a normal Western diet to a gluten-free vegan diet [12]. The present finding adds strength to our previous report, indicating that diet may influence atheroprotective anti-PC in RA.

A high frequency of MetS has previously been reported in RA patients [59-61]. In these patients an association between MetS and disease activity, as well as coronary calcification, has been shown $[60,61]$, suggesting that the increased prevalence of coronary heart disease in RA patients may, at least in part, be attributed to inflammation and change of fat metabolism.

In the present RA population every fourth to fifth patient had rheumatoid cachexia, irrespectively of which of the two definitions for cachexia were used. There is no standard definition of this condition as reviewed by Summers et al. [62], which is why the frequency of rheumatoid cachexia varies. The cachexia and muscle wasting found here could not reflect the changes in body composition that occur with age [63], as the reference population was matched for age and sex [40]. Agerelated muscle wasting is a separate condition named sarcopenia. Cachexia in chronic inflammatory diseases is suggested to be associated with increased morbidity [19]. Mostly, the morbidity has been attributing the loss of body lean mass [13], whereas the coincidental increase of fat mass has not been considered in this context. In the present study it was obvious that FM above the 50th percentile was, together with FFM below the 25th percentile, associated with dyslipidemia as were increased levels of total cholesterol, LDL and oxLDL and also low levels of anti-PC. These patients are therefore suggested to have an increased risk of CVD and premature mortality $[10,11,64]$. In fact, they also had high frequencies of hypertension and MetS.

Low FFM alone, irrespective of FM, was not associated with these risk factors for CVD. By contrast, only one of the patients 
was severely emaciated with extremely low BMI known to be associated with cardiovascular mortality in RA [65].

A large proportion of the patients were centrally obese, which is in line with earlier reports [16]. This fact might contribute to the increased presence of risk factors for CVD in the patients with rheumatoid cachexia.

In the present cohort of patients we did not find that DAS28 or CRP differed between those with cachexia and the rest of the patients, probably related to the fact that most patients had low inflammatory activity. However, when separating the patients into those with low DAS28 and those with DAS28 corresponding to moderate activity it was found that the latter had lower FFM and higher FM than the former. Thus, the inflammation per se might have contributed to the derangement in body composition found here and also described previously $[18,41,66]$. A further explanation could be that patients with DAS28 of moderate activity reported lower energy intake than those with low activity.

\section{Conclusion}

In our cohort of RA patients with low disease activity and BMI in the upper reference range every fourth to fifth patient had rheumatoid cachexia, a condition that was not associated with the observed increased intake of fatty acids. Rheumatoid cachexia defined as FFMI below the 25th percentile and FMI above the 50th percentile was associated with risk factors for CVD, including raised cholesterol and LDL and also decreased levels of the atheroprotective marker anti-PC as well as a high frequency of hypertension. We thus propose this definition of rheumatoid cachexia to be used, as it verifies that it is associated with increased morbidity. However, patients on a Mediterranean-like diet had high anti-PC levels in spite of a similar frequency of cachexia, which may provide some protection against CVD events.

\section{Competing interests}

The authors declare that they have no competing interests.

\section{Authors' contributions}

ACE was responsible for the design of the study, for all measurements, for analyzing the data and was responsible for writing the manuscript. $\mathrm{NH}$ had responsibility for analyzing the FFQ. JF was responsible for assays of lipids and anti-PC antibodies. TC had an active role in the design of the study, in analyzing adipose tissue and an advisory role. $\mathrm{IH}$ took part in the design of the study and has been senior advisor in all parts of the research and manuscript preparation. All authors read and approved the final manuscript.

\section{Additional files}

The following Additional files are available online:

\section{Additional file 1}

A table in Word format listing blood lipids, inflammatory marker, hypertension and metabolic syndrome in relation to different categories of body composition.

See http://www.biomedcentral.com/content/ supplementary/ar2643-S1.doc

\section{Acknowledgements}

We are grateful to Inger Vedin for analyzing oxLDL and anti-PC antibodies, and to Siv Tengblad for analyzing fatty acids in adipose tissue. This work was supported by grants from The Swedish Rheumatism Association, King Gustav V 80 years foundation, Capio, The Stig Thunes foundation, the Swedish Research Council and the regional agreement on medical training and clinical research (ALF) between Stockholm county council and the Karolinska Institute.

\section{References}

1. Symmons DP: Mortality in rheumatoid arthritis. $\mathrm{Br} J$ Rheumatol 1988, 27(Suppl 1):44-54.

2. Naz SM, Symmons DP: Mortality in established rheumatoid arthritis. Best Pract Res Clin Rheumatol 2007, 21:871-883.

3. Maradit-Kremers H, Nicola PJ, Crowson CS, Ballman KV, Gabriel SE: Cardiovascular death in rheumatoid arthritis: a populationbased study. Arthritis Rheum 2005, 52:722-732.

4. Boers M, Nurmohamed MT, Doelman CJ, Lard LR, Verhoeven AC, Voskuyl AE, Huizinga TW, Stadt RJ van de, Dijkmans BA, Linden S van der: Influence of glucocorticoids and disease activity on total and high density lipoprotein cholesterol in patients with rheumatoid arthritis. Ann Rheum Dis 2003, 62:842-845.

5. Park YB, Choi HK, Kim MY, Lee WK, Song J, Kim DK, Lee SK: Effects of antirheumatic therapy on serum lipid levels in patients with rheumatoid arthritis: a prospective study. $A m J$ Med 2002, 113:188-193.

6. Georgiadis AN, Papavasiliou EC, Lourida ES, Alamanos Y, Kostara $C$, Tselepis AD, Drosos AA: Atherogenic lipid profile is a feature characteristic of patients with early rheumatoid arthritis: effect of early treatment - a prospective, controlled study. Arthritis Res Ther 2006, 8:R82.

7. Kim SH, Lee CK, Lee EY, Park SY, Cho YS, Yoo B, Moon HB: Serum oxidized low-density lipoproteins in rheumatoid arthritis. Rheumatol Int 2004, 24:230-233.

8. Binder CJ, Horkko S, Dewan A, Chang MK, Kieu EP, Goodyear CS, Shaw PX, Palinski W, Witztum JL, Silverman GJ: Pneumococcal vaccination decreases atherosclerotic lesion formation: molecular mimicry between Streptococcus pneumoniae and oxidized LDL. Nat Med 2003, 9:736-743.

9. Frostegard J, Huang YH, Ronnelid J, Schafer-Elinder L: Plateletactivating factor and oxidized LDL induce immune activation by a common mechanism. Arterioscler Thromb Vasc Biol 1997, 17:963-968.

10. Su J, Georgiades A, Wu R, Thulin T, de Faire U, Frostegard J: Antibodies of IgM subclass to phosphorylcholine and oxidized LDL are protective factors for atherosclerosis in patients with hypertension. Atherosclerosis 2006, 188:160-166.

11. Sjoberg BG, Su J, Dahlbom I, Gronlund H, Wikstrom M, Hedblad $B$, Berglund G, de Faire U, Frostegard J: Low levels of IgM antibodies against phosphorylcholine-A potential risk marker for ischemic stroke in men. Atherosclerosis 2009 in press.

12. Elkan AC, Sjoberg B, Kolsrud B, Ringertz B, Hafstrom I, Frostegard $\mathrm{J}$ : Gluten-free vegan diet induces decreased $L D L$ and oxidized LDL levels and raised atheroprotective natural antibodies 
against phosphorylcholine in patients with rheumatoid arthritis: a randomized study. Arthritis Res Ther 2008, 10:R34.

13. Roubenoff R, Roubenoff RA, Ward LM, Holland SM, Hellmann DB: Rheumatoid cachexia: depletion of lean body mass in rheumatoid arthritis. Possible association with tumor necrosis factor. $J$ Rheumatol 1992, 19:1505-1510.

14. Walsmith J, Abad L, Kehayias J, Roubenoff R: Tumor necrosis factor-alpha production is associated with less body cell mass in women with rheumatoid arthritis. J Rheumatol 2004, 31:23-29.

15. Elkan AC, Engvall IL, Tengstrand B, Cederholm T, Hafstrom I: Malnutrition in women with rheumatoid arthritis is not revealed by clinical anthropometrical measurements or nutritional evaluation tools. Eur J Clin Nutr 2008, 62:1239-1247.

16. Westhovens R, Nijs J, Taelman V, Dequeker J: Body composition in rheumatoid arthritis. $\mathrm{Br} J$ Rheumatol 1997, 36:444-448.

17. Walsmith J, Roubenoff R: Cachexia in rheumatoid arthritis. Int $J$ Cardiol 2002, 85:89-99.

18. Roubenoff R, Roubenoff RA, Cannon JG, Kehayias JJ, Zhuang H, Dawson-Hughes B, Dinarello CA, Rosenberg IH: Rheumatoid cachexia: cytokine-driven hypermetabolism accompanying reduced body cell mass in chronic inflammation. J Clin Invest 1994, 93:2379-2386.

19. Akner $G$, Cederholm T: Treatment of protein-energy malnutrition in chronic nonmalignant disorders. Am J Clin Nutr 2001, 74:6-24.

20. Gomez-Vaquero C, Nolla JM, Fiter J, Ramon JM, Concustell R, Valverde J, Roig-Escofet $D$ : Nutritional status in patients with rheumatoid arthritis. Joint Bone Spine 2001, 68:403-409.

21. Morgan SL, Anderson AM, Hood SM, Matthews PA, Lee JY, Alarcon GS: Nutrient intake patterns, body mass index, and vitamin levels in patients with rheumatoid arthritis. Arthritis Care Res 1997, 10:9-17.

22. Laar MA van de, Nieuwenhuis JM, Former-Boon M, Hulsing J, Korst JK van der: Nutritional habits of patients suffering from seropositive rheumatoid arthritis: a screening of 93 Dutch patients. Clin Rheumatol 1990, 9:483-488.

23. Marcora S, Lemmey A, Maddison P: Dietary treatment of rheumatoid cachexia with beta-hydroxy-beta-methylbutyrate, glutamine and arginine: a randomised controlled trial. Clin Nutr 2005, 24:442-454.

24. Hunter DJ, Rimm EB, Sacks FM, Stampfer MJ, Colditz GA, Litin LB, Willett WC: Comparison of measures of fatty acid intake by subcutaneous fat aspirate, food frequency questionnaire, and diet records in a free-living population of US men. Am J Epidemiol 1992, 135:418-427.

25. Tjonneland A, Overvad K, Thorling E, Ewertz M: Adipose tissue fatty acids as biomarkers of dietary exposure in Danish men and women. Am J Clin Nutr 1993, 57:629-633.

26. Garland M, Sacks FM, Colditz GA, Rimm EB, Sampson LA, Willett WC, Hunter DJ: The relation between dietary intake and adipose tissue composition of selected fatty acids in US women. Am J Clin Nutr 1998, 67:25-30.

27. Wolk A, Vessby $B$, Ljung $\mathrm{H}$, Barrefors $\mathrm{P}$ : Evaluation of a biological marker of dairy fat intake. Am J Clin Nutr 1998, 68:291-295.

28. Arnett FC, Edworthy SM, Bloch DA, McShane DJ, Fries JF, Cooper NS, Healey LA, Kaplan SR, Liang MH, Luthra HS, Medsger TA Jr, Mitchell DM, Neustadt DH, Pinals RS, Schaller JG, Sharp JT, Wilder RL, Hunder GG: The American Rheumatism Association 1987 revised criteria for the classification of rheumatoid arthritis. Arthritis Rheum 1988, 31:315-324.

29. Criteria Committee of the American Heart Association: Nomenclature and Diagnosis. 9th edition. New York, USA: American Heart Association; 1994.

30. Prevoo ML, van 't Hof MA, Kuper $\mathrm{HH}$, van Leeuwen MA, Putte LB van de, van Riel PL: Modified disease activity scores that include twenty-eight-joint counts. Development and validation in a prospective longitudinal study of patients with rheumatoid arthritis. Arthritis Rheum 1995, 38:44-48.

31. Ekdahl C, Eberhardt K, Andersson SI, Svensson B: Assessing disability in patients with rheumatoid arthritis. Use of a Swedish version of the Stanford Health Assessment Questionnaire. Scand J Rheumatol 1988, 17:263-271.

32. Mancia G, De Backer G, Dominiczak A, Cifkova R, Fagard R, Germano G, Grassi G, Heagerty AM, Kjeldsen SE, Laurent S, Narkiewicz $K$, Ruilope L, Rynkiewicz A, Schmieder RE, Boudier HA, Zanchetti A, Vahanian A, Camm J, De Caterina R, Dean V, Dick- stein K, Filippatos G, Funck-Brentano C, Hellemans I, Kristensen SD, McGregor K, Sechtem U, Silber S, Tendera M, Widimsky P, et al.: 2007 Guidelines for the Management of Arterial Hypertension: The Task Force for the Management of Arterial Hypertension of the European Society of Hypertension (ESH) and of the European Society of Cardiology (ESC). J Hypertens 2007, 25:1105-87.

33. Messerer M, Johansson SE, Wolk A: The validity of questionnaire-based micronutrient intake estimates is increased by including dietary supplement use in Swedish men. J Nutr 2004, 134:1800-1805

34. Bergström LEH, Becker W, Hagman U: Vad är det vi äter? Livsmedelstabeller och livsmedelsdatabaser ger klart besked. Vår föda 2. Administration SNF; 1997.

35. Swedish Nutrition Recommendations Objectified (SNO) [http://www.slv.se]

36. Boberg M, Croon LB, Gustafsson IB, Vessby B: Platelet fatty acid composition in relation to fatty acid composition in plasma and to serum lipoprotein lipids in healthy subjects with special reference to the linoleic acid pathway. Clin Sci (Lond) 1985, 68:581-587.

37. World Health Organization: Physical status: the use and interpretation of anthropometry. Geneva, Switzerland: WHO; 1995.

38. Alberti KG, Zimmet $P$, Shaw J: Metabolic syndrome - a new world-wide definition. A Consensus Statement from the International Diabetes Federation. Diabet Med 2006, 23:469-480.

39. Abernathy RP, Black DR: Healthy body weights: an alternative perspective. Am J Clin Nutr 1996, 63:448S-451S.

40. Schutz Y, Kyle UU, Pichard C: Fat-free mass index and fat mass index percentiles in Caucasians aged 18-98 y. Int J Obes Relat Metab Disord 2002, 26:953-960.

41. Engvall IL, Elkan AC, Tengstrand B, Cederholm T, Brismar K, Hafstrom I: Cachexia in rheumatoid arthritis is associated with inflammatory activity, physical disability, and low bioavailable insulin-like growth factor. Scand J Rheumato/ 2008, 37:1-8.

42. Baylin A, Kabagambe EK, Siles X, Campos H: Adipose tissue biomarkers of fatty acid intake. Am J Clin Nutr 2002, 76:750-757

43. Wolk $A$, Ljung $H$, Vessby $B$, Hunter $D$, Willett WC: Effect of additional questions about fat on the validity of fat estimates from a food frequency questionnaire. Study Group of MRS SWEA. Eur J Clin Nutr 1998, 52:186-192.

44. Hodson L, Skeaff CM, Fielding BA: Fatty acid composition of adipose tissue and blood in humans and its use as a biomarker of dietary intake. Prog Lipid Res 2008, 47:348-380.

45. Wolk A, Furuheim M, Vessby B: Fatty acid composition of adipose tissue and serum lipids are valid biological markers of dairy fat intake in men. J Nutr 2001, 131:828-833.

46. Garaulet M, Perez-Llamas F, Perez-Ayala M, Martinez P, de Medina FS, Tebar FJ, Zamora S: Site-specific differences in the fatty acid composition of abdominal adipose tissue in an obese population from a Mediterranean area: relation with dietary fatty acids, plasma lipid profile, serum insulin, and central obesity. Am J Clin Nutr 2001, 74:585-591.

47. London SJ, Sacks FM, Caesar J, Stampfer MJ, Siguel E, Willett WC: Fatty acid composition of subcutaneous adipose tissue and diet in postmenopausal US women. Am J Clin Nutr 1991, 54:340-345.

48. Jacobsson L, Lindgarde F, Manthorpe R, Akesson B: Correlation of fatty acid composition of adipose tissue lipids and serum phosphatidylcholine and serum concentrations of micronutrients with disease duration in rheumatoid arthritis. Ann Rheum Dis 1990, 49:901-905.

49. Salminen E, Heikkila S, Poussa T, Lagstrom H, Saario R, Salminen $S$ : Female patients tend to alter their diet following the diagnosis of rheumatoid arthritis and breast cancer. Prev Med 2002 34:529-535

50. Martin $\mathrm{RH}$ : The role of nutrition and diet in rheumatoid arthritis. Proc Nutr Soc 1998, 57:231-234.

51. Fukuda W, Yamazaki T, Akaogi T, Hayashi H, Kusakabe T, Tsubouchi Y, Kawahito Y, Inoue M, Yoshikawa T: Malnutrition and disease progression in patients with rheumatoid arthritis. Mod Rheumatol 2005, 15:104-107.

52. McCann K: Nutrition and rheumatoid arthritis. Explore (NY) 2007, 3:616-618. 
53. Frostegard J, Wu R, Giscombe R, Holm G, Lefvert AK, Nilsson J: Induction of T-cell activation by oxidized low density lipoprotein. Arterioscler Thromb 1992, 12:461-467.

54. Frostegard J, Nilsson J, Haegerstrand A, Hamsten A, Wigzell H, Gidlund M: Oxidized low density lipoprotein induces differentiation and adhesion of human monocytes and the monocytic cell line U937. Proc Natl Acad Sci USA 1990, 87:904-908.

55. Winyard PG, Tatzber F, Esterbauer H, Kus ML, Blake DR, Morris $\mathrm{CJ}$ : Presence of foam cells containing oxidised low density lipoprotein in the synovial membrane from patients with rheumatoid arthritis. Ann Rheum Dis 1993, 52:677-680.

56. Nordin Fredrikson G, Hedblad B, Berglund G, Nilsson J: Plasma oxidized LDL: a predictor for acute myocardial infarction? J Intern Med 2003, 253:425-429.

57. Panagiotakos DB, Pitsavos C, Chrysohoou C, Skoumas I, Stefanadis C: Five-year incidence of cardiovascular disease and its predictors in Greece: the ATTICA study. Vasc Med 2008, 13:113-121.

58. Vincent-Baudry S, Defoort C, Gerber M, Bernard MC, Verger P, Helal O, Portugal H, Planells R, Grolier P, Amiot-Carlin MJ, Vague P, Lairon D: The Medi-RIVAGE study: reduction of cardiovascular disease risk factors after a 3-mo intervention with a Mediterranean-type diet or a low-fat diet. Am J Clin Nutr 2005, 82:964-971.

59. Bolton-Smith C, Woodward M, Tavendale R: Evidence for agerelated differences in the fatty acid composition of human adipose tissue, independent of diet. Eur J Clin Nutr 1997, 51:619-624.

60. Karvounaris SA, Sidiropoulos PI, Papadakis JA, Spanakis EK, Bertsias GK, Kritikos HD, Ganotakis ES, Boumpas DT: Metabolic syndrome is common among middle-to-older aged Mediterranean patients with rheumatoid arthritis and correlates with disease activity: a retrospective, cross-sectional, controlled, study. Ann Rheum Dis 2007, 66:28-33.

61. Chung CP, Oeser A, Solus JF, Avalos I, Gebretsadik T, Shintani A, Raggi P, Sokka T, Pincus T, Stein CM: Prevalence of the metabolic syndrome is increased in rheumatoid arthritis and is associated with coronary atherosclerosis. Atherosclerosis 2008, 196:756-763.

62. Summers GD, Deighton CM, Rennie MJ, Booth AH: Rheumatoid cachexia: a clinical perspective. Rheumatology (Oxford) 2008, 47:1124-1131.

63. Roubenoff R, Rall LC: Humoral mediation of changing body composition during aging and chronic inflammation. Nutr Rev 1993, 51:1-11.

64. Stevens RJ, Douglas KM, Saratzis AN, Kitas GD: Inflammation and atherosclerosis in rheumatoid arthritis. Expert Rev Mol Med 2005, 7:1-24.

65. Kremers HM, Nicola PJ, Crowson CS, Ballman KV, Gabriel SE: Prognostic importance of low body mass index in relation to cardiovascular mortality in rheumatoid arthritis. Arthritis Rheum 2004, 50:3450-3457.

66. Arshad A, Rashid R, Benjamin K: The effect of disease activity on fat-free mass and resting energy expenditure in patients with rheumatoid arthritis versus noninflammatory arthropathies/ soft tissue rheumatism. Mod Rheumatol 2007, 17:470-475. 